University of Nebraska - Lincoln

DigitalCommons@University of Nebraska - Lincoln

\title{
Late-Holocene dune activity linked to hydrological drought, Nebraska Sand Hills, USA
}

\author{
Joseph A. Mason \\ University of Nebraska-Lincoln \\ James B. Swinehart \\ University of Nebraska-Lincoln \\ Ronald J. Goble \\ University of Nebraska-Lincoln, rgoble2@unl.edu \\ David B. Loope \\ University of Nebraska-Lincoln, dloope1@unl.edu
}

Follow this and additional works at: https://digitalcommons.unl.edu/conservationsurvey

Part of the Geology Commons, Geomorphology Commons, Hydrology Commons, Paleontology Commons, Sedimentology Commons, Soil Science Commons, and the Stratigraphy Commons

Mason, Joseph A.; Swinehart, James B.; Goble, Ronald J.; and Loope, David B., "Late-Holocene dune activity linked to hydrological drought, Nebraska Sand Hills, USA" (2004). Conservation and Survey Division. 457.

https://digitalcommons.unl.edu/conservationsurvey/457

This Article is brought to you for free and open access by the Natural Resources, School of at DigitalCommons@University of Nebraska - Lincoln. It has been accepted for inclusion in Conservation and Survey Division by an authorized administrator of DigitalCommons@University of Nebraska - Lincoln. 


\title{
Late-Holocene dune activity linked to hydrological drought, Nebraska Sand Hills, USA
}

\author{
Joseph A. Mason, ${ }^{1,2 *}$ James B. Swinehart, ${ }^{1,2}$ Ronald J. Goble ${ }^{2}$ and \\ David B. Loope ${ }^{2}$
}

$\left({ }^{1}\right.$ Conservation and Survey Division, 113 Nebraska Hall, University of Nebraska, Lincoln 68588-0517, USA; ${ }^{2}$ Department of Geosciences, 214 Bessey Hall, University of Nebraska, Lincoln 68588-0340, USA)

Received 27 August 2002; revised manuscript accepted 17 December 2002

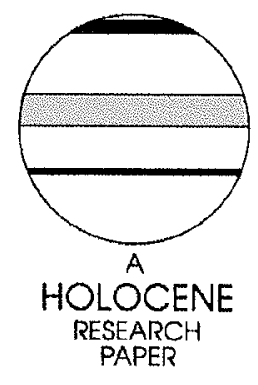

\section{Introduction}

Dunefields are distributed across the Great Plains of North America, including large areas in which there are few other records of Holocene climate. These dunefields are now largely stabilized by vegetation, but were episodically active during the Holocene (Muhs and Wolfe, 1999; Loope and Swinehart, 2000; Forman et al., 2001; Holliday, 2001). If dunefield activation represents a direct response to climatic change, then dunefield sediments can provide a rich stratigraphic record of both temporal and spatial variation of climate during the Holocene.

Full realization of this potential remains limited by persistent difficulty in unambiguously linking the aeolian stratigraphy at individual study sites to regional palaeoclimate. The widespread occurrence of blowouts (deflation hollows) resulting from local vegetation disturbance, largely by cattle, in otherwise stable dunefields demonstrates that disturbance can cause local sand transport even in the present relatively humid climate. Past disturbance by

*Author for correspondence. Present address: Department of Geography, University of Wisconsin-Madison, 384 Science Hall, 550 N. Park St. Madison, WI 53706, USA (e-mail: jmason2@unl.edu)

(C) Arnold 2004 bison grazing or wildfires could have caused at least local aeolian activity independent of climatic change.

Regionally synchronous episodes of aeolian sand transport are likely to have been a direct response to climatic change, but, in the case of short-lived late-Holocene episodes, it is often difficult to make a strong case for synchroneity between, or even within, dunefields. This in part reflects the need to date aeolian deposits indirectly, using ${ }^{14} \mathrm{C}$ ages of organic matter in buried soils, which provide only minimum ages for underlying aeolian deposits (Wang et al., 1996). The ${ }^{14} \mathrm{C}$ age of buried soil organic matter can also significantly overestimate ages of overlying aeolian sand, because of the potentially long residence time (100-2000 yr) of soil organic carbon in North American grassland soils (Broecker et al., 1956; Paul et al., 1964; Wang et al., 1996), and because of the potential for truncation of soils by aeolian erosion before burial. Even minor truncation could increase the ${ }^{14} \mathrm{C}$ age obtained from the upper part of a buried A horizon by hundreds of years, because of the steep gradient of ${ }^{14} \mathrm{C}$ age with depth observed in some buried soils (Caseldine and Matthews, 1985) and predicted by modelling studies (Wang et al., 1996). Although the numerous ${ }^{14} \mathrm{C}$ ages obtained from buried soils have provided valuable insight into the chronology of Great Plains dunefield activity, further 
refinement of that chronology will require more extensive application of other dating methods. In particular, optical dating (also referred to as optically stimulated luminescence [OSL] dating) directly determines the time since sand grains were last exposed to sunlight during aeolian transport (Stokes and Swinehart, 1997; Aitken, 1998).

In this paper we demonstrate that integration of upland and interdune stratigraphic records in the largest Great Plains dunefield provides compelling evidence for extensive late-Holocene aeolian activity directly linked to hydrological drought (drought defined by reduction in groundwater level or surface water flow; Wilhite and Glantz, 1985). We use ${ }^{14} \mathrm{C}$ dating of plant macrofossils in interdune wetlands, together with optical dating of upland aeolian sand and ${ }^{14} \mathrm{C}$ dating of intercalated palaeosols, to establish a case for regionally synchronous aeolian activity. More importantly, the interdune stratigraphy links aeolian activity to reduced groundwater recharge, indicative of drier-than-present climate rather than local disturbance.

\section{Regional setting}

The Nebraska Sand Hills (Figure 1) form the largest sand sea in North America (Swinehart, 1990; Loope and Swinehart, 2000), now stabilized by grassland vegetation. The barchanoid ridge and megabarchan dunes up to $130 \mathrm{~m}$ high which dominate the central Sand Hills probably began forming during the Pleistocene, but some of these dunes migrated almost a full wavelength during the Holocene (Swinehart, 1990; Stokes et al., 1999). In the central Sand Hills, the $1960-90$ mean annual temperature was $8.5^{\circ} \mathrm{C}$ and

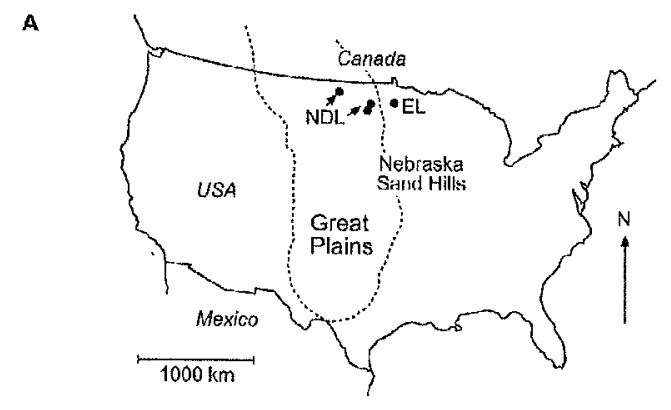

B

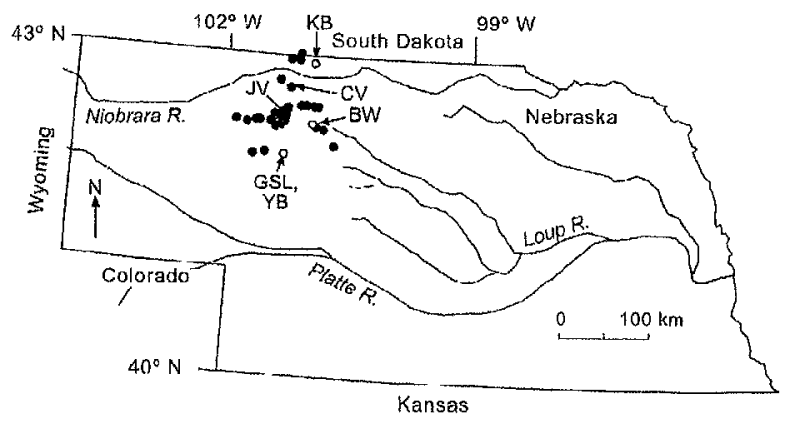

Figure 1 Location maps. (A) Location of Nebraska Sand Hills and other localities mentioned in the text, within the Great Plains of North America. NDL $=$ North Dakota lake study sites of Fritz et al., 2000, and Yu and Ito, 1999 (Moon, Coldwater and Rice lakes); EL = Elk Lake, Minnesota. (B) Detailed map of study sites within the Sand Hills. Open circles are locations discussed in the text. GSL $=$ Gudmundsen Sandhills Laboratory; $\mathrm{YB}=$ Yao's Blowout; $\mathrm{BW}=$ Briefcase Wayside; JV = Jumbo Valley; $\mathrm{CV}=$ Cutcomb Valley, $\mathrm{KB}=$ Kroeger Blowout. Filled circles indicate additional interdune peatlands similar to Jumbo Valley and Cutcomb Valley, in which a sand layer occurs within $1 \mathrm{~m}$ below the valley surface. mean annual precipitation was about $500 \mathrm{~mm}$ (Wilhite and Hubbard, 1990). This precipitation recharges a major regional aquifer, underlying the Sand Hills and occupying the saturated portion of the late-Quatemary aeolian sand, subjacent Pleistocene or Pliocene silts, sands and gravels, and sandstones of the Ogallala Group (Miocene) (Swinehart and Diffendal, 1990). Within this aquifer, shallow local ground water flow systems are superimposed on the regional flow, which is to the east, except where diverted northward or southward toward incised stream valleys (Bleed, 1990).

Interdune valleys in the Sand Hills can contain dry mineral soils, wet mineral soils with shallow water tables, peat or shallow lakes. Wet interdunes with lush vegetation, on either mineral soil or peat, contrast strongly with dry interdunes in which vegetation density is almost as low as on adjacent dunes. At the Gudmundsen Sand Hills Laboratory (Figure 1) these contrasts in vegetation are related to subtle differences in groundwater hydrology, created by the contrasting topography of adjacent dunes. Gosselin et al. (1999) used piezometer networks to compare groundwater flow systems in two interdunes about $5 \mathrm{~km}$ apart, one a wet valley with dense vegetation and the other a dry valley with much less dense vegetation. The water table is usually 1.5 to $3.0 \mathrm{~m}$ below the ground surface in the dry interdune, but is within $0.5 \mathrm{~m}$ of the surface during at least part of each year in the wet interdune. Groundwater mounds sufficient to drive a local flow system have developed under the high-relief dunes bordering the wet valley, and some of the groundwater recharged under the dunes is discharged on the adjacent valley floor. A similar local flow system is not present under the dry valley and lower dunes adjacent to it. Groundwater discharges on the wet valley floor but passes under the dry interdune as part of the regional flow system.

Although topography is responsible for present contrasts between nearby wet and dry interdunes, the hydrology of many interdunes could be altered by climatic change, without modification of the local topography. The degree to which local flow develops varies in response to changes in recharge rate (Winter, 1983). Modern observations indicate that the heights of watertable mounds beneath the dunes respond to short-term variations in precipitation rate (Gosselin et al., 1999). A sustained reduction in recharge could reduce the height of groundwater mounds observed under the present climate, weakening or eliminating some local flow systems, increasing the depth to the water-table under the valley floors, and transforming wet interdunes into dry valleys (Figure 2).

\section{Interdune stratigraphy}

Peat up to $7 \mathrm{~m}$ thick accumulated intermittently throughout the Holocene in many interdunes of the north-central Sand Hills (Figure 1) (Ponte, 1995). Springs in the peat-filled valleys confirm the presence of well-developed local flow systems, which maintain a shallow water table within about $0.5 \mathrm{~m}$ of the valley floor (Harvey et al., 2001). Multiple sand layers, $<1 \mathrm{~cm}$ to $3 \mathrm{~m}$ thick, are interbedded with the peat in parts of many interdune wellands. In at least 29 interdunes, the uppermost sand layer occurs within $1 \mathrm{~m}$ of the ground surface (Figure 1). The stratigraphy in two interdune valleys (JV and CV, Figure 1) that contain shallow sand layers was investigated in detail using vibracore and hand auger transects (Figures 3 and 4).

We interpret the upper sand layer in these valleys as a sheet of aeolian sand that was derived from adjacent dunes and prograded across the interdune surface at a time when the valley floor was dry and sufficiently devegetated to allow sand transport. Where the upper sand layer is thickest, its upper surface has a hummocky topography, characteristic of aeolian sand sheets (Figure 3B). The upper sand layer locally contains aeolian ripple laminae 
A HUMID CLIMATE: Wet valley floor, peat accumulation possible

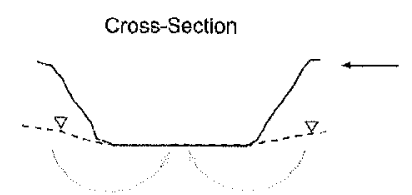

B DROUGHT: Dry valley floor, sparse vegetation, sand transport possible
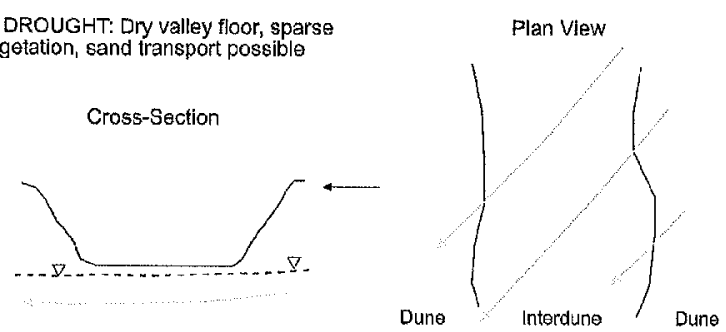

Figure 2 Schematic diagram of a Nebraska Sand Hills interdune, illustrating the conceptual model of contrasting groundwater flow systems under (A) humid conditions (e.g., present climate) and (B) prolonged drought and reduced groundwater recharge. In (A), groundwater mounds form under dunes, driving local flow system with discharge in the interdune. Each case is represented by both a plan view and a cross-section showing the surface topography (solid black lines), groundwater table (dashed lines) and groundwater flow (grey lines with arrows, flow paths projected onto plane of cross-section or plan view).

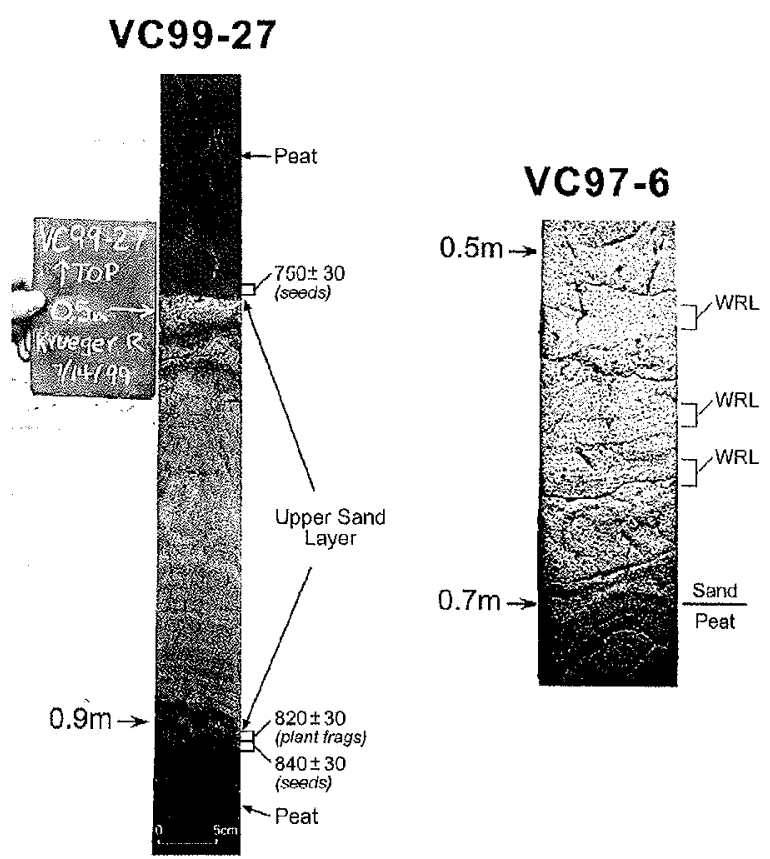

Figure 4 Upper sand layer in parts of vibracores. Examples of uncalibrated radiocarbon ages $\left({ }^{14} \mathrm{C}\right.$ yr BP) of plant macrofossils bracketing the sand layer are shown for VC99-27. The sand layer in VC97-6 contains wind-ripple lamination (WRL). The upper boundary of the sand layer is not visible in VC97-6.

A

Jumbo Valley

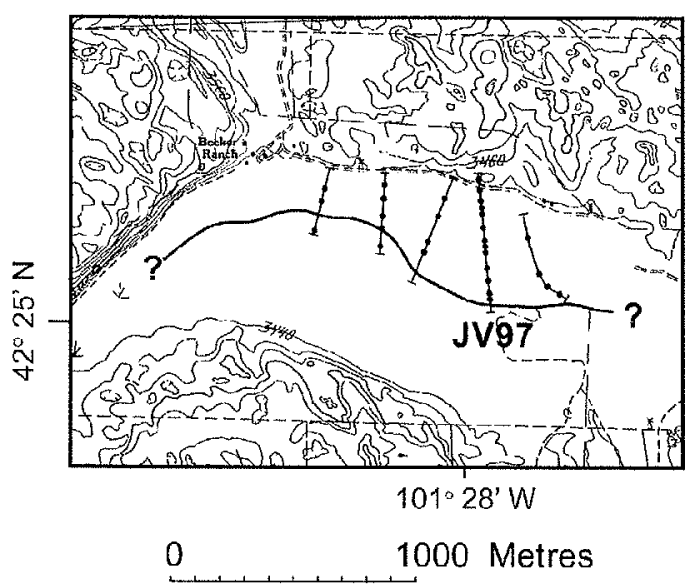

$B$

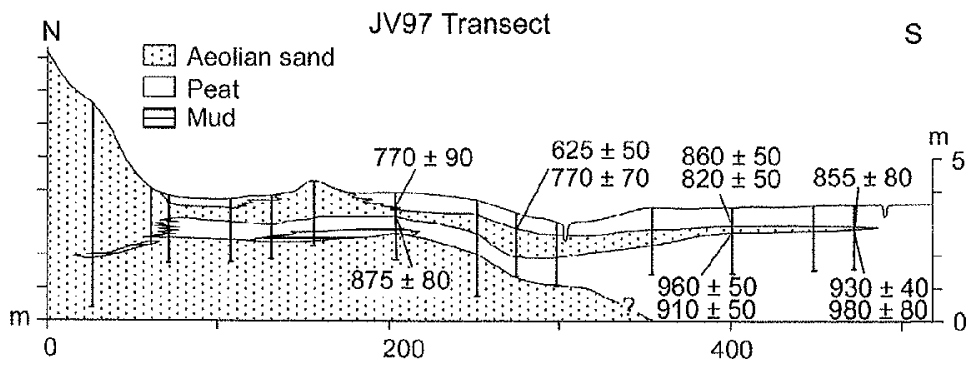

Figure 3 Vibracore transects in Jumbo Valley interdune peatland (Cutcomb Valley was investigated using similar transects). (A) Topographic map (from USGS Wolf Lake 7.5' quadrangle) illustrating distribution of the upper sand layer as determined by vibracore transects (black lines with dots showing core locations; some dots represent two or more closely spaced cores) and hand augering. (B) Example of stratigraphy in one vibracore transect (location shown on $\mathrm{A}$ ), including uncalibrated radiocarbon ages $\left({ }^{4} \mathrm{C}\right.$ yr $\left.\mathrm{BP}\right)$ of plant macrofossils. 
(Figure 4), although sedimentary structures are not visible in most cores. The layer is most extensive south of low-relief dunes, and less extensive immediately southeast of the steep lee face of highrelief dunes (Figure $3 \mathrm{~A}$ ). Given the predominance of northerly to northwesterly sand-transporting winds in the Sand Hills (Ahlbrandt and Fryberger, 1980), this distribution is consistent with an aeolian origin: sand transport from uplands to interdunes should have been more limited on the relatively sheltered lee side of the high-relief dunes than in areas immediately downwind of low-relief dunes. Finally, in one core, sand-filled desiccation cracks in the underlying peat indicate that the upper sand layer was deposited on a dry surface.

Other explanations for the upper sand layer are less plausible. Alluvial fans fed by ephemeral gullies dissecting dune slopes (Sweeney and Loope, 2001) occur along the northern edge of the peat-filled valleys, but sand deposition on the fans does not extend far into the interdunes because of dense wetland vegetation. Fans are also present mainly on the lee side of particularly high-relief dunes, where the sand layer is least extensive. Larger inflowing streams that could have deposited the sand layer are not likely to have existed since the present dune topography was established.

The age of the upper sand layer in the two interdunes studied in detail is constrained by 40 accelerator mass spectrometer ${ }^{14} \mathrm{C}$ ages of plant macrofossils (Figures 4 and 5; Table 1). The most likely maximum age of the upper sand layer is between 950 and $750 \mathrm{cal} . \mathrm{BP}$ and the most likely minimum age is between 650 and 700 cal. BP.

\section{Upland stratigraphy}

We focused on three upland sites (Figure 6) where the most recent major episode of aeolian activity is represented by 1.5 to $6.5 \mathrm{~m}$ of wind-ripple laminated sand overlying a prominent buried soil (palaeosol 2, Figure 6). This stratigraphy clearly represents a transition from relative stability and soil formation to rapid aeolian sand deposition. In each section, a weakly developed soil with an A/C profile (palaeosol 1) buried by a few tens of centimetres of light-coloured sand represents minor recent sand transport.

At each site, samples for optical dating were collected and the uppermost $5 \mathrm{~cm}$ of buried soil $\mathrm{A}$ horizons were sampled for ${ }^{14} \mathrm{C}$ dating of soil organic matter. Palaeosol 1 contains abundant modern roots and was sampled only at Yao's Blowout; as expected, this sample yielded a modern ${ }^{14} \mathrm{C}$ age (Figure 6; Table 2)
Optical ages were determined on 90 to $125 \mu \mathrm{m}$ quartz grains, using the single aliquot regeneration (SAR) protocol (Murray and Roberts, 1998; Murray and Wintle, 2000). Each age was based on 17-20 aliquots and dose rates determined from $\mathrm{K}, \mathrm{U}$ and $\mathrm{Th}$ content measured by inductively coupled plasma mass spectrometry (ICP-MS) inductively coupled plasma atomic emission spectrometry (ICP-AES) and X-ray fluorescent spectrometry (XRFS). Hydrofluoric-nitric-perchloic acid digestion was used to dissolve samples for ICP-MS analysis. This digestion appears to yield complete dissolution of $\mathrm{U}$ and $\mathrm{Th}$, based upon comparison with analyses of representative duplicate samples using fusion flux dissolution.

OSL measurements were carried out on a Daybreak Nuclear and Medical Systems reader equipped with green $(514 \mathrm{~nm})$ and infrared diodes, an EMI 9635Q photomultiplier, UG-11 filter, and an on-plate irradiator with a $100 \mathrm{mCi} 90 \mathrm{Sr}$ source delivering approximately $0.05 \mathrm{~Gy} \mathrm{~s}^{-1}$. Stimulation was by green diodes operated at a power level on the sample of approximately $24 \mathrm{~mW} \mathrm{~cm}^{-2}$. A preheat of $240^{\circ} \mathrm{C}$ was chosen based upon an observed preheat plateau between $220^{\circ} \mathrm{C}$ and $280^{\circ} \mathrm{C}$. Cutheat and sample stimulation temperatures were $160^{\circ} \mathrm{C}$ and $125^{\circ} \mathrm{C}$, respectively. Sample behaviour was monitored using dose-recovery and IR response tests. No anomalous behaviour was noted, although data from individual aliquots were rejected based upon poor signal response or large errors in the recycling ratio or associated with the calculated $D_{e}$ (equivalent dose), such as poor fits to the growth curve. With the exception of the uppermost sample in Figure 6A, OSL measurements provided no evidence of partial bleaching. This sample showed the asymmetric frequency distribution (Olley et al., 1998; 1999), correlation of standardized intensity with $D_{e}$ (Colls et al., 2001) and rising $\mathrm{D}_{\mathrm{c}}(\mathrm{t})$ (Bailey et al., 2002) associated with partial bleaching. Optical ages and supporting data are reported in Table 3.

Bulk soil samples used for ${ }^{14} \mathrm{C}$ dating were wet-sieved at 63 $\mu \mathrm{m}$, to remove fine roots and concentrate organic matter associated with silt and clay fractions, and material passing the sieve was submitted for age determination. Radiocarbon laboratories used either the humic acid fraction or total organic matter for dating (Table 2).

The optical ages are in correct stratigraphic sequence at each site (Figure 6). The mean of the five optical ages obtained from aeolian sand between palaeosol 1 and palaeosol 2 at all three sites, representing the last significant aeolian activity, is 892 a (years before $\mathrm{AD} 2000$; equivalent to a calibrated ${ }^{14} \mathrm{C}$ age of $842 \mathrm{cal}$. $B P)$. This age falls within the $\pm 1 \sigma$ range of four of the five
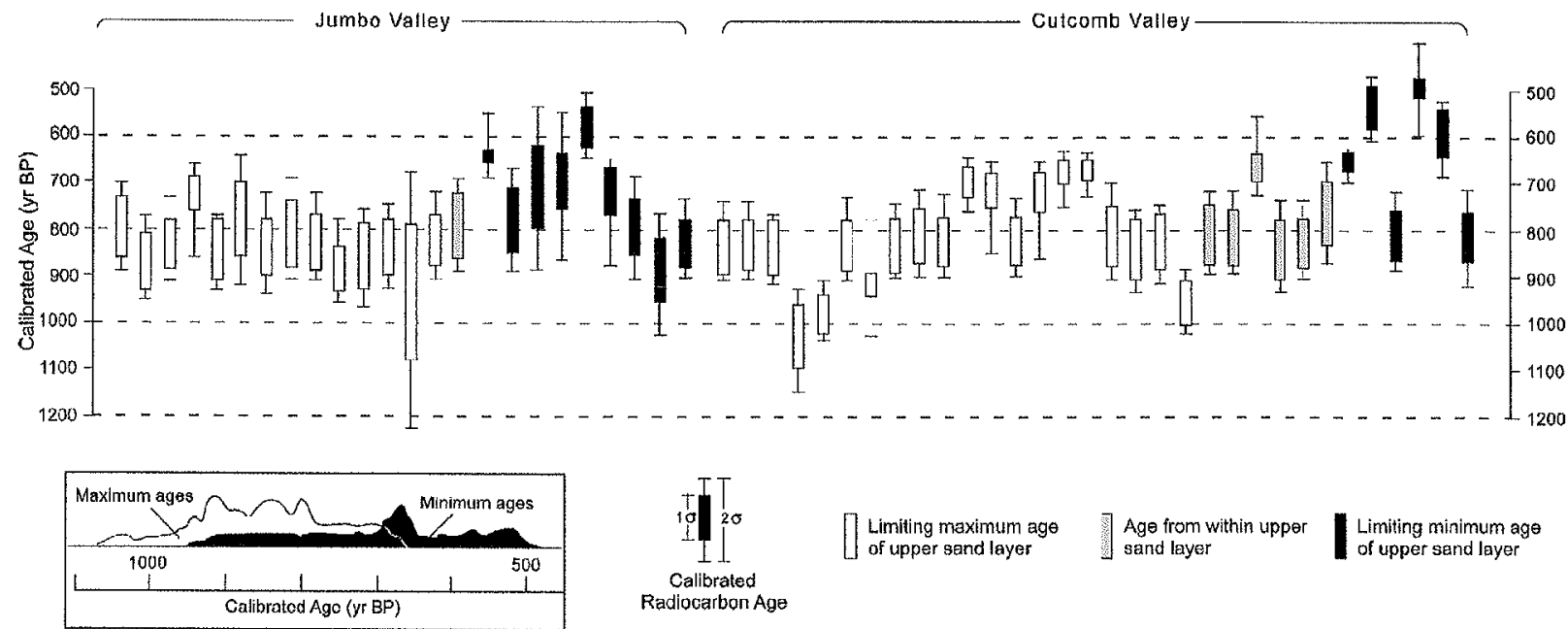

Figure 5 Box plots of calibrated ${ }^{14} \mathrm{C}$ ages (OxCal v. 3.5; Bronk Ramsey, 1995) of plant macrofossils immediately below, within or immediately above the upper sand layer in two interdunes. Inset shows probability summation curve (Meyer et al., 1995) derived from 'above' and 'below' ages. 
Table 1 Radiocarbon ages from plant macrofossils in interdune wetland vibracores

\begin{tabular}{|c|c|c|c|c|c|c|}
\hline Vibracore & Field sample & Depth $(\mathrm{cm})$ & Lab. number & $\begin{array}{l}\text { Radiocarbon age }{ }^{1} \\
\left({ }^{14} \mathrm{C} \text { yr BP }\right)\end{array}$ & $\begin{array}{l}\text { Calibrated age } \\
\text { range }^{2} \text { (cal. BP) }\end{array}$ & Material dated \\
\hline \multicolumn{7}{|c|}{ Jumbo Valley } \\
\hline $99-14$ & RCJ00-79 & $88-89$ & NSRL-11853 & $885 \pm 30$ & $910-720$ & Plant fragments \\
\hline $99-13$ & RCJ00-80 & $83-84$ & NSRL-1 1858 & $995 \pm 30$ & $970-790$ & Carex seeds \\
\hline \multirow[t]{4}{*}{$99-11 b$} & RCJ00-81 & $48-49$ & NSRL-11854 & $715 \pm 30$ & $710-570$ & Carex seeds \\
\hline & RCJ00 -82 & $64-67$ & NSRL-11852 & $930 \pm 30$ & $930-750$ & Sparaganium seed \\
\hline & RCJ00-83 & $67-70$ & NSRL-1 1856 & $840 \pm 30$ & $880-680$ & Sparaganium seed \\
\hline & RCJO0-84 & $67-70$ & NSRL-11857 & $970 \pm 30$ & $950-790$ & Carex seeds \\
\hline $99-12$ & RCJO0-85 & $66-67$ & NSRL-11859 & $865 \pm 36$ & $910-690$ & Carex seeds \\
\hline \multirow[t]{2}{*}{$97-6$} & RCJ97-22 & $52-53$ & CAMS-43777 & $770 \pm 90$ & $910-560$ & Plant fragments \\
\hline & RCJ97-21 & $71-72$ & CAMS-43776/46025 & $875 \pm 80$ & $940-670$ & Plant fragments \\
\hline \multirow[t]{2}{*}{$97-23$} & RCJ97-7 & $48-49$ & CAMS-43762/46017 & $770 \pm 70$ & $890-570$ & Carex seeds \\
\hline & RCJ97 -8 & $48-49$ & CAMS $-43763 / 46018$ & $625 \pm 50$ & $670-530$ & Carex seeds \\
\hline \multirow[t]{3}{*}{$97-20$} & RCJ97-14 & $53-54$ & CAMS-43769/46020 & $820 \pm 50$ & $900-670$ & Carex seeds \\
\hline & RCJ97-11 & $77-78$ & CAMS-43766 & $960 \pm 50$ & $960-740$ & Carex seeds \\
\hline & $\mathrm{RC} 97-10$ & $78-79$ & CAMS-43765 & $910 \pm 50$ & $930-710$ & Carex seeds \\
\hline $97-22$ & RCJ97-19 & $72-73$ & CAMS- 43774 & $930 \pm 40$ & $930-740$ & Carex seeds and plant fragments \\
\hline $99-6$ & RCJ00-78 & $115-116$ & NSRL-11850 & $1010 \pm 30$ & $980-800$ & Carex seeds \\
\hline $99-1$ & RCJO0-76 & $98-100$ & NSRL-11848 & $990 \pm 45$ & $990-780$ & Carex seeds \\
\hline $99-2$ & RCJO0-24 & $35-36$ & OS- 25526 & $910 \pm 50$ & $930-710$ & Carex seeds \\
\hline 99-9 & RCJO0-74 & $80-83$ & NSRL-11851 & $960 \pm 35$ & $950-770$ & Carex seeds \\
\hline $99-8$ & RCJ00-27 & $82-83$ & OS- 25529 & $1040 \pm 120$ & $1250-700$ & Carex seeds \\
\hline \multirow[t]{3}{*}{$99-15$} & $\mathrm{RCJ} 00-86$ & $60-61$ & NSRL- 11860 & $935 \pm 30$ & $930-760$ & Carex seeds \\
\hline & RCJ00-87 & $61-62$ & NSRL-1 1861 & $1020 \pm 50$ & $1050-790$ & Carex seeds \\
\hline & RCJ00-88 & $79-80$ & NSRL-11862 & $925 \pm 35$ & $930-740$ & Carex seeds \\
\hline \multicolumn{7}{|c|}{ Cutcomb Valley } \\
\hline $99-23$ & RCJ00-120 & & NSRL-11874 & $950 \pm 35$ & $930-760$ & Menyanthes seeds \\
\hline $99-32$ & RCJO0-119 & $39-41$ & NSRL-1 1873 & $945 \pm 35$ & $930-760$ & Sparaganium seed \\
\hline \multirow[t]{3}{*}{$99-34$} & RCJO0-51 & $97-98$ & OS-25857 & $910 \pm 30$ & $920-740$ & Carex seeds \\
\hline & RCJ00-53 & $101-102$ & OS-26061 & $960 \pm 30$ & $940-790$ & Carex seeds \\
\hline & $\mathrm{RCJ} 00-54$ & $101-102$ & OS-26166 & $1130 \pm 45$ & $1170-950$ & Carex seeds \\
\hline \multirow[t]{2}{*}{$99-35$} & RCJ00-57 & $95-96$ & OS -27150 & $1090 \pm 30$ & $1060-930$ & Plant fragments \\
\hline & RCJ00 58 & $96-97$ & OS-26064 & $940 \pm 35$ & $930-750$ & Plant fragments \\
\hline \multirow[t]{2}{*}{$99-36$} & RCJ00-35 & $58-60$ & OS-25641 & $915 \pm 35$ & $920-740$ & Carex seeds \\
\hline & RCJ00-36 & $60-61$ & OS- 25642 & $1020 \pm 35$ & $1050-800$ & Carex seeds \\
\hline \multirow[t]{5}{*}{$99-31$} & $\mathrm{RCJ} 00-94$ & $91-92$ & NSRL-11838 & $970 \pm 45$ & $960-760$ & Carex seeds \\
\hline & RCJ00-95 & $111-112$ & NSRL-11839 & $940 \pm 30$ & $930-760$ & Helianthes seeds \\
\hline & RCJ00-96 & $140-141$ & NSRL-11840 & $950 \pm 30$ & $930-770$ & Carex seeds \\
\hline & RCJ00-97 & $142-143$ & NSRL-11841 & $920 \pm 40$ & $930-740$ & Carex seeds \\
\hline & RCJ00-98 & $142-143$ & NSRL-11842 & $930 \pm 30$ & $930-750$ & Carex seeds \\
\hline \multirow[t]{3}{*}{$99-27$} & RCJ00-101 & $47-48$ & NSRL-11845 & $750 \pm 30$ & $730-655$ & Carex seeds \\
\hline & RCJ00-102 & $89-90$ & NSRL-11846 & $820 \pm 30$ & $790-670$ & Plant fragments \\
\hline & RCJ00-103 & $90-91$ & NSRL-11847 & $840 \pm 30$ & $880-680$ & Carex and Menyanthes seeds \\
\hline \multirow[t]{4}{*}{$99-28$} & RCJ00-104 & $44-45$ & NSRL-11834 & $925 \pm 30$ & $920-750$ & Carex seeds \\
\hline & $\mathrm{RCJ} 00-105$ & $45-47$ & NSRL-11835 & $525 \pm 40$ & $640-500$ & Carex seeds \\
\hline & RCJ00-106 & $84-85$ & NSRL-11836 & $940 \pm 30$ & $930-760$ & Carex seeds \\
\hline & RCJ00-107 & $85-86$ & NSRL-11637 & $840 \pm 35$ & $890-680$ & Menyanthes seeds \\
\hline \multirow[t]{4}{*}{$99-29$} & RCJ00-108 & $36-38$ & NSRL-11863 & $490 \pm 50$ & $630-430$ & Carex seeds \\
\hline & RCJ00-110 & $58-60$ & NSRL-11865 & $865 \pm 35$ & $910-690$ & Carex seeds \\
\hline & RCJ00-111 & $60-61$ & NSRL-11866 & $790 \pm 35$ & $780-660$ & Carex seeds \\
\hline & RCJO0-112 & $60-61$ & NSRL-11867 & $790 \pm 30$ & $760-665$ & Menyanthes seeds \\
\hline \multirow[t]{3}{*}{$99-30$} & RCJ00-67 & $59-60$ & OS-26159 & $700 \pm 45$ & $720-560$ & Plant fragments \\
\hline & RCJ00-68 & $66-68$ & OS -26067 & $930 \pm 50$ & $940-730$ & Carex seeds \\
\hline & RCJ00-69 & $66-68$ & OS-26068 & $990 \pm 35$ & $970-790$ & Menyanthes seeds \\
\hline \multirow[t]{2}{*}{$99-38$} & RCJO0-116 & $44-46$ & NSRL-11831 & $965 \pm 50$ & $960-750$ & Carex seeds \\
\hline & RCJO0-117 & $70-72$ & NSRL-11832 & $1070 \pm 40$ & $1060-920$ & Menyanthes seeds \\
\hline $99-39$ & RCJOO-114 & $113-114$ & NSRL-11829 & $965 \pm 35$ & $950-780$ & Carex seeds \\
\hline
\end{tabular}

${ }^{\mathrm{I}}$ Corrected for isotopic fractionation.

${ }^{2}$ Calibrated ages were calculated using OxCal v. 3.5 (Bronk Ramsey, 1995); range is 95\% confidence interval.

individual ages. The optical ages are also concordant with ${ }^{14} \mathrm{C}$ ages of organic matter in buried soils. Optical ages between palaeosols 1 and 2 provide much stronger evidence than the ${ }^{14} \mathrm{C}$ ages for a relatively brief, synchronous episode of sand transport at these three localities separated by up to $120 \mathrm{~km}$. The ${ }^{14} \mathrm{C}$ ages obtained from palaeosol 2 range over more than 500 years, which could be consistent with an alternative hypothesis that the aeolian sand deposition that buried that soil was asynchronous. The variation in ${ }^{14} \mathrm{C}$ ages of palaeosol 2 may reflect varying mean residence time of soil carbon at burial and/or partial truncation of 


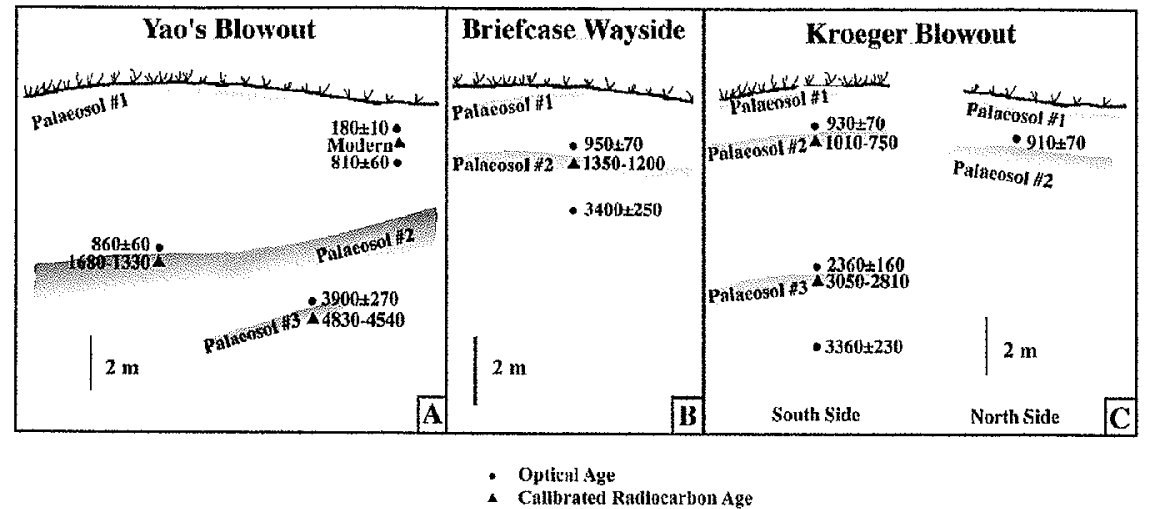

Figure 6 Stratigraphy at upland sites. Modern land surface is at the top of each column; dark bands represent buried soils, Radiocarbon ages are represented by $95 \%$ confidence limits of ages after calibration, in cal, BP ( = before AD 1950). Optical ages are in years before AD $2000 \pm 1$ o; 50 years must be subtracted from optical ages for direct comparison with ${ }^{14} \mathrm{C}$ ages. The youngest age in (A) is an overestimate because the sample displayed evidence of partial bleaching.

Table 2 Radiocarbon ages from soil organic matter at upland sites

\begin{tabular}{lllll}
\hline Site & Lab. number & $\begin{array}{l}\text { Radiocarbon age } \\
\left({ }^{14} \mathrm{C} \text { yr BP) }\right.\end{array}$ & $\begin{array}{l}\text { Calibrated age range } \\
\text { (cal. BP) }\end{array}$ & Material dated \\
\hline Yao's Blowout & CURL-5322 & $102 \%$ Modern & & Humic acid \\
Yao's Blowout & Beta-44974 & $1590 \pm 70$ & $1680-1330$ & Total organic matter \\
Yao's Blowout & CURL-5321 & $4150 \pm 40$ & $4830-4540$ & Humic acid \\
Briefcase Wayside & CURL-5323 & $1380 \pm 35$ & $1350-1200$ & Humic acid \\
Kroeger Blowout & Beta-50435, ETH-9088 & $980 \pm 55$ & $1010-750$ & Total organic matter \\
Kroeger Blowout & Beta-50438, ETH-9089 & $2910 \pm 60$ & $3260-2880$ & Total organic matter \\
Kroeger Blowout & CURL-5324 & $2820 \pm 35$ & $3050-2810$ & Humic acid \\
\hline
\end{tabular}

${ }^{1}$ Stratigraphic context within site shown in Figure 6.

${ }^{2}$ Corrected for isotopic fractionation.

"Calibrated ages were calculated using OxCal v. 3.5 (Bronk Ramsey, 1995); range is $95 \%$ confidence interval.

${ }^{4}$ From Stokes and Swinehart (1997)

that palaeosol at Yao's Blowout, supported by field observations of a very sharp upper boundary. In addition, it is clear that the end of aeolian activity postdating palaeosol 2 cannot be determined by ${ }^{14} \mathrm{C}$ dating.

\section{Discussion}

At both upland and interdune study sites, aeolian activity occurred between about 1000 and 700 years ago (optical ages from 810 to $950 \mathrm{a}$ at upland sites, ${ }^{14} \mathrm{C}$ age range of approximately 650 to 950 cal. BP from interdunes). This activity may have been discontinuous but was not interrupted for long enough to allow soil development or peat accumulation. The most parsimonious explanation of these observations is that aeolian activity occurred at about the same time at all upland and interdune study sites. This interpretation in itself strongly suggests that the dunefield was responding to regional climatic conditions rather than local disturbance.

Formation of the upper sand layer within the peat-filled interdunes provides more conclusive evidence linking aeolian activity to a period of dry climate. A dry, sparsely vegetated valley floor allowing sand transport would only develop if the present high water table was lowered; this would occur if the local ground water flow system was weakened or shut off because of reduced discharge. This change must have been temporary, however, because peat accumulation resumed after upper sand layer formation. A period of drier-than-present climate and reduced groundwater recharge is the only plausible explanation for this fluctuation in groundwater hydrology. Although ongoing stream incision has lowered the regional water table in parts of the Sand Hills, this is a unidirectional process and cannot have caused restoration of wet conditions. Even if heavy bison grazing or fire locally destroyed vegetation on adjacent dunes, sand blown from the disturbed area could not have advanced hundreds of metres across a wet and densely vegetated valley floor.

The magnitude of climatic change necessary for an aeolian sand sheet to advance across a given interdune wetland must vary, depending on how the local topography influences groundwater flow. Here we emphasize that formation of the upper sand layer occurred in response to a period of hydrological drought that was modest, but still exceeded any occurring in the subsequent 700 years. Fibrous peat with very well-preserved plant macrofossils, which cannot have been exposed to oxidizing conditions above the water table for any extended period of time, occurs within $1 \mathrm{~m}$ below the upper sand layer at many sites. Thus, the water table was probably not more than $1 \mathrm{~m}$ below the land surface during upper sand layer formation in many interdunes. In addition, sediment records from several Sand Hills lakes do not indicate complete desiccation in the late Holocene (Mason et al., 1997), and the presence of isolated boreal wetland plant populations within the central Sand Hills (Steinhauer et al., 1996) suggests that some interdune wetlands persisted throughout the Holocene. On the other hand, even if the hydrological drought that produced the upper sand layer was modest, droughts since then have not been of sufficient magnitude or duration to allow significant sand transport into the interdune wetlands that we studied. This includes the eighteenth- and nineteenth-century droughts that led 
Table 3 Selected field and laboratory data, and OSL results

\begin{tabular}{|c|c|c|c|c|c|c|c|c|c|c|c|}
\hline \multirow[t]{2}{*}{ Sample } & \multirow{2}{*}{$\begin{array}{l}\text { Depth } \\
\text { (m) }\end{array}$} & \multicolumn{2}{|c|}{$\mathrm{H}_{2} \mathrm{O}$ content $(\%)$} & \multirow{2}{*}{$\begin{array}{l}\mathrm{K}_{2} \mathrm{O} \\
(\%)\end{array}$} & \multirow{2}{*}{$\begin{array}{l}\text { Th } \\
\text { (ppm) }\end{array}$} & \multirow{2}{*}{$\begin{array}{l}\mathrm{U} \\
(\mathrm{ppm})\end{array}$} & \multirow{2}{*}{$\begin{array}{l}\mathrm{D}_{\text {curmici }}{ }^{2} \\
\left(\mathrm{~Gy} \cdot \mathrm{a}^{-1} \cdot 10^{3}\right)\end{array}$} & \multirow{2}{*}{$\begin{array}{l}\mathrm{D}_{\text {Total }}{ }^{3} \\
\left(\text { Gy }^{-1} \cdot 10^{3}\right)\end{array}$} & \multirow{2}{*}{$\begin{array}{l}\mathrm{D}_{e}^{4} \\
\left(\mathrm{~Gy} \pm 1 \sigma_{s}\right)\end{array}$} & \multirow{2}{*}{$\begin{array}{l}\text { Aliquots } \\
\text { (n) }\end{array}$} & \multirow{2}{*}{$\begin{array}{l}\text { Age }^{5} \\
(a \pm 1 \sigma)\end{array}$} \\
\hline & & In situ & Saturated & & & & & & & & \\
\hline \multicolumn{12}{|c|}{ Yao's Blowout } \\
\hline 00RJG1 & 0.4 & 4.8 & 25.2 & 1.90 & 4.8 & 0.9 & 0.24 & $2.20 \pm 0.25$ & $0.39 \pm 0.02$ & 100 & $180 \pm 10^{6}$ \\
\hline 00RJG3 & 1.0 & 5.3 & & 1.94 & 4.4 & 1.0 & 0.22 & $2.18 \pm 0.15$ & $1.76 \pm 0.04$ & 19 & $810 \pm 60$ \\
\hline 00RJG4 & 6.3 & 8.3 & & 1.84 & 5.6 & 1.0 & 0.11 & $2.02 \pm 0.15$ & $1.73 \pm 0.03^{7}$ & 30 & $860 \pm 60$ \\
\hline 00R.JG6 & 8.5 & 5.2 & & 1.81 & 3.5 & 0.8 & 0.09 & $1.84 \pm 0.14$ & $7.22 \pm 0.16$ & 39 & $3900 \pm 270$ \\
\hline \multicolumn{12}{|c|}{ Briefcase Wayside } \\
\hline 00RJG10 & 2.0 & 4.5 & & 1.43 & 4.0 & 0.9 & 0.19 & $1.74 \pm 0.12$ & $1.65 \pm 0.03$ & 18 & $950 \pm 70$ \\
\hline 00RJG12 & 3.5 & 4.8 & & 1.47 & 4.1 & 0.7 & 0.16 & $1.69 \pm 0.13$ & $5.74 \pm 0.20$ & 20 & $3400 \pm 250$ \\
\hline \multicolumn{12}{|c|}{ Kroeger Blowout, South Side } \\
\hline 00RJG17 & 1.3 & 4.3 & 22.9 & 2.00 & 5.1 & 1.1 & 0.21 & $2.31 \pm 0.16$ & $2.16 \pm 0.05$ & 18 & $930 \pm 70$ \\
\hline 00R.JG15 & 6.3 & 8.7 & 25.4 & 2.07 & 7.9 & 1.6 & 0.11 & $2.44 \pm 0.17$ & $5.75 \pm 0.11$ & 19 & $2360 \pm 160$ \\
\hline 00RJG13 & 8.4 & 7.9 & & 2.01 & 6.3 & 1.5 & 0.09 & $2.28 \pm 0.17$ & $7.67 \pm 0.16$ & 19 & $3360 \pm 230$ \\
\hline \multicolumn{12}{|c|}{ Kroeger Blowout, North Side } \\
\hline $00 \mathrm{RJG} 22$ & 1.3 & 3.5 & & 1.91 & 7.0 & 1.2 & 0.21 & $2.27 \pm 0.17$ & $2.06 \pm 0.07$ & 19 & $910 \pm 70$ \\
\hline
\end{tabular}

${ }^{\mathrm{I} D e p t h}$ of sample below current land surface. Samples are arranged in order of increasing depth at each sample location.

${ }^{2}$ Cosmic ray dose rate, calculated from locational data and depth of burial (Prescott and Hutton, 1994).

${ }^{3}$ Total dose rate.

${ }^{4}$ Equivalent dose.

Fears before AD 2000.

'Lowest $5 \%$ of aliquots yield an age of $86 \pm 12$ a. Use of the 'leading edge' of the distribution (Lepper et al., 2000 ) yields an age of $116 \pm 26$ a.

7 Multiple aliquot additive palaeodose is $1.74 \mathrm{~Gy}$, based on 40 dises.

to upland dune activity in several parts of the Great Plains (Muhs and Holliday, 1995; Wolfe et al., 2001)

Other palaeoclimate records from the Great Plains and adjacent. areas provide evidence for potentially correlative dry periods between 1000 and 700 years ago. High-resolution records from sediments of Moon, Rice and Coldwater lakes, all in North Dakota, indicate one or more relatively brief episodes of high salinity (inferred from diatoms and/or ostracode-shell $\mathrm{Mg} / \mathrm{Ca}$ ratios) between 600 and $900 \mathrm{cal}$. BP (Fritz et al., 2000; Yu and Ito, 1999). Given the uncertainty in dating both our Sand Hills records and the North Dakota lake sediments, we hesitate to correlate the formation of the upper sand layer with specific salinity peaks in the lake records. Nonetheless, we note that, in each of the North Dakota lakes, at least one peak in the $600-900 \mathrm{cal}$. BP interval is near the maximum reconstructed salinity (or $\mathrm{Mg} / \mathrm{Ca}$ ratio) observed in the past 2000 years. In annually laminated sediments of Elk Lake, Minnesota, there are multiple peaks of Al content, interpreted as aeolian dust influx, between about 500 and 900 varve years before AD 1980 (Dean, 1997). An early tree-ring study at a western Nebraska site adjacent to the Sand Hills indicated several lengthy droughts, 800 to 550 years ago (Weakly, 1962). However, the same study also reported long droughts within the past 500 years, and it is impossible to determine the relative severity of any of the droughts listed in Weakly's brief report.

In dunefields spanning much of the north-south extent of the Great Plains, many radiocarbon ages between abont 900 and 1500 cal. BP have been obtained from organic matter in soils buried by aeolian sand (Madole, 1994; Arbogast, 1996; Muhs and Wolfe, 1999; Holliday, 2001). Based upon ${ }^{14} \mathrm{C}$ ages alone, it is possible to interpret the range of buried soil ages as indicative of regionally asynchronous aeolian activity. By analogy with our upland sites, however, the aeolian sand overlying those palaeosols may actually have been deposited during a single episode of sustained and widespread aridity, correlative with the dry period we have identified in the Sand Hills. More extensive application of optical dating would allow the latter hypothesis to be tested.
At our upland and interdune study sites, the last major episode of aeolian sand transport occurred between 1000 and 700 years ago, but, at some other upland sites in the Sand Hills and many localities in other Great Plains dunefields, there is strong evidence for one or more episodes of aeolian sand transport within the past 500 years (Muhs et al., 1997; Stokes and Swinehart, 1997; Muhs and Wolfe, 1999; Forman et al., 2001; Wolfe et al., 2001). Some of these recent episodes may reflect local disturbance or local drought, and others may correlate with episodes of high salinity and aeolian dust flux within the past 500 years that have been inferred from lake-sediment records from the Northern Great Plains and adjacent regions (Dean, 1997; Fritz et al., 2000; Yu and Ito, 1999).

Thus, the stratigraphic record of hydrological drought in the central Sand Hills wetlands records only one dry episode in the past 1000 years, in contrast to some upland dunefield records and high-resolution palaeoclimate proxies derived from lake sediments. We propose that the Sand Hills wetlands provide a filtered record of only those dry periods of sufficient magnitude or duration to exceed the threshold for sand transport into the interdune. If so, this record, including multiple sand layers below the upper one discussed here, can play a key role in identifying the most extreme events among the many late Holocene dry periods identified in high-resolution records of Great Plains palaeoclimate.

\section{Conclusions}

Both upland and interdune study sites in the central Sand Hills of Nebraska indicate an episode of aeolian activity between 1000 and 700 years ago. Optical ages from upland sites provide stronger evidence for synchronous regional activity than do ${ }^{14} \mathrm{C}$ ages from buried soils, although results of both dating methods are concordant. The unique insight provided by interdune sites is that aeolian sand transport between 950 and $650 \mathrm{cal}$. BP occurred under conditions of hydrological drought, when the groundwater 
flow system was altered by reduced recharge. This conclusion, together with evidence of synchronous aeolian activity at widely spaced upland sites, confirms a link between dunefield activity and dry climate that is difficult to establish from upland sites alone. Interdune wetland stratigraphy is also valuable as a 'filtered' record, preserving evidence of only the more extreme dry periods during the Holocene.

\section{Acknowledgements}

We thank Chuck Markley for the original field insight on the upper sand layers and Ed Harvey, Mike Ponte and Mark Sweeney for their ideas and help in the field. Special thanks to the Hanson, Huffman, Krueger and Ravenscroft families, the Nature Conservancy and the Sand Hills Task Force. Tom Brown (LLNL) and Scott Stine helped obtain the first set of radiocarbon ages. Funding from the National Science Foundation, through the Earth System History Program (EAR97-09942) and a Biocomplexity Incubation Activity grant (DEB-0084075), the Conservation and Survey Division and Department of Geosciences of the University of Nebraska-Lincoln. We thank D.R. Muhs and S. Wolfe for helpful reviews.

\section{References}

Aitken, M.J. 1998: An introduction to optical dating: the dating of Quaternary sediments by the use of photon-stimulated luminescence. Oxford: Oxford University Press.

Ahlbrandt, T.S. and Fryberger, S.G. 1980: Eolian deposits in the Nebraska Sand Hills. US Geological Survey Professional Paper 1120A. Washington, DC: US Government Printing Office.

Arbogast, A.F. 1996: Stratigraphic evidence for late-Holocene aeolian sand mobilization and soil formation in south-central Kansas, USA. Journal of Arid Environments 34, 403-14.

Bailey, R.M., Singarayer, J., Ward, S. and Stokes, S. 2002: Identification of partial bleaching using De as a function of illumination time. Abstracts, Luminescence and Electron Spin Resonance (LED) 2002, 10th International Conference on LED Dating, 24-28 June 2002, Reno, Nevada,

Bleed, A. 1990: Groundwater. In Bleed, A. and Flowerday, C., editors, An atlas of the Sand Hills, Lincoln, Nebraska: Conservation and Survey Division, University of Nebraska, 67-92.

Broecker, W.S., Kulp, J.L. and Tucek, C.S. 1956: Lamont natural radiocarbon measurements III. Science 124, 154-62.

Bronk Ramsey, C. 1995: Radiocarbon calibration and analysis of stratigraphy: the OxCal program. Radiocarbon 37, 425-30.

Caseldine, C.J. and Matthews, J.A. $1985:{ }^{14} \mathrm{C}$ dating of palaeosols, pollen analysis and landscape change: studies from the low- and midalpine belts of southern Norway. In Boardman, J., editor, Soils and Quaternary landscape evolution, Chichester: Wiley, 87-116.

Colls, A.E., Stokes, S., Blum, M.D. and Straffin, E. 2001: Age limits on the Late Quaternary evolution of the upper Loire River. Quaternary Science Reviews 20, 743-50.

Dean, W.E. 1997: Rates, timing, and cyclicity of Holocene eolian activity in north-central United States; evidence from varved lake sediments. Geology 25, 331-34.

Forman, S.L., Oglesby, R. and Webb, R.S. 2001: Temporal and spatial patterns of Holocene dune activity on the Great Plains of North America; megadroughts and climate links. Global and Planetary Change 29, 1-29. Fritz, S.C., Ito, E., Yu, Z., Laird, K.R. and Engstrom, D.R. 2000: Hydrologic variation in the Northern Great Plains during the last two millennia. Quaternary Research 53, 175-84.

Gosselin, D.C., Drda, S., Harvey, F.E. and Goeke, J. 1999: Hydrologic setting of two two interdunal valleys in the Central Sand Hills of the Nebraska. Ground Water 37, 924-32.

Harvey, F.E., Swinehart, J.B. and Kurtz, T.M. 2001: Hydrogeology and hydrochemistry of the Jumbo and Pullman Valley Fens - Cherry County, Nebraska. Lincoln: University of Nebraska-Lincoln, Conservation and Survey Division, $104 \mathrm{pp}$.
Holliday, V.T. 2001: Stratigraphy and geochronology of upper Quaternary eolian sand on the Southern High Plains of Texas and New Mexico, United States. Geological Society of America Bulletin 113, 88-108.

Lepper, K., Agersnap Larsen, N. and McKeever, S.W.S. 2000: Equivalent dose distribution analysis of Holocene eolian and fluvial quartz sands from Central Oklahoma. Radiation Meastrements 32, 603-608.

Loope, D.B. and Swinehart, J.B. 2000: Thinking like a dunefield: geologic history in the Nebraska Sand Hills. Great Plains Research 10, 5-35. Madole, R.F. 1994: Stratigraphic evidence of desertification in the westcentral Great Plains within the past 1000 yr. Geology 22, 483-86.

Mason, J.P., Swinehart, J.B. and Loope, D.B. 1997: Holocene history of lacustrine and marsh sediments in a dune-blocked drainage, southwestern Nebraska Sand Hills, USA. Journal of Paleolimnology 17, 67-83.

Meyer, G.A., Wells, S.G. and Jull, A.J.T. 1995: Fire and alluvial chronology in Yellowstone National Park; climatic and intrinsic controls on Holocene geomorphic processes. Geological Society of America Bulletin 107, $1211-30$.

Muhs, D.R. and Holliday, V.T. 1995: Evidence of active dune sand on the Great Plains in the 19th century from accounts of early explorers. Quaternary Research 43, 198-208.

Muhs, D.R. and Wolfe, S.A. 1999: Sand dunes of the Northern Great Plains of Canada and the United States. In Lemmen, D.S. and Vance, R.E., editors, Holocene climate and environmental change in the Palliser Triangle; a geoscientific context for evaluation of the impacts of climate change on the southern Canadian prairies, Ottawa: Geological Survey of Canada Bulletin 534, 183-97.

Muhs, D.R., Stafford, T.W., Jr., Swinehart, J.B., Cowherd, S.D., Mahan, S.A., Bush, C.A., Madole, R.F. and Maat, P.B. 1997: Late Holocene eolian activity in the mineralogically mature Nebraska Sand Hills. Quaternary Research 48, 162-76.

Murray, A.S. and Roberts, R.G. 1998: Measurement of the equivalent dose in quartz using a regenerative-dose single-aliquot protocol. Radiation Measurements 29, 503-15.

Murray, A.S. and Wintle, A.G. 2000: Luminescence dating of quartz using an improved single-aliquot regenerative-dose protocol. Radiation Measurements 32, 57-73.

Olley, J.M., Caitcheon, G. and Murray, A.S. 1998: The distribution of apparent dose as determined by optically stimulated luminescence in small aliquots of fluvial quartz: implications for dating young sediments. Quaternary Geochronology (QSR) 17, 1033-40.

Olley, J.M., Caitcheon, G. and Roberts, R.G. 1999: The origin of dose distribution in fluvial sediments, and the prospect of dating single grains from fluvial deposits using optically stimulated luminescence. Radiation Measurements 30, 207-17.

Paul, E.A., Campbell, C.A., Rennie, D.A. and McCallum, K.J. 1964: Investigations of the dynamics of soil humus utilizing carbon dating techniques, 8th International Congress of Soil Science, volume 3. Bucharest: Academy of the Socialist Republic of Romania, 201-208.

Ponte, M.R. 1995: Eolian origin of sand within interdune peat, central Nebraska Sand Hills. Unpublished manuscript, University of NebraskaLincoln.

Prescott, J.R. and Hutton, J.T. 1994: Cosmic ray contributions to dose rates for luminescence and ESR dating: large depths and long-term time variations. Radiation Measurements 23, 497-500.

Steinhauer, G., Rolfsmeier, S. and Hardy, J.P. 1996: Inventory and floristics of Sandhills fens in Cherry County, Nebraska. Transactions of the Nebraska Academy of Sciences 23, 9-21.

Stokes, S. and Swinehart, J.B. 1997: Middle- and late-Holocene dune reactivation in the Nebraska Sand Hills, USA. The Holocene 7, 263-72. Stokes, S., Rich, J., Swinehart, J.B. and Loope, D.B. 1999: Holocene timing of megabarchan dune construction in the Nebraska Sand Hills. Geological Society of America Abstracts with Programs 31, A231.

Sweeney, M.R. and Loope, D.B. 2001: Holocene dune-sourced alluvial fans in the Nebraska Sand Hills. Geomorphology 38, 31-46.

Swinehart, J.B. 1990: Wind-blown deposits. In Bleed, A. and Flowerday, C., editors, An atlas of the Sand Hills, Lincoln, Nebraska: Conservation and Survey Division, University of Nebraska, 43-56.

Swinehart, J.B. and Diffendal, R.F. Jr 1990: Geology of the pre-dune strata. In Bleed, A. and Flowerday, C., editors, An atlas of the Sand Hills, Lincoln, Nebraska: Conservation and Survey Division, University of Nebraska, 29-42.

Wang, Y., Amundson, R. and Trumbore, S. 1996: Radiocarbon dating of soil organic matter. Quaternary Research 45, 282-88. 
Weakly, H.E. 1962: History of drought in Nebraska. Joumal of Soil and Water Conservation 17, 271-74.

Wilhite, D.A. and Glantz, M.H. 1985: Understanding thedrought phenomenon: the role of definitions. Water International 10 , 111-20.

Wilhite, D.A. and Hubbard, K.G. 1990: Climate. In Bleed, A. and Flowerday, C. editors, An atlas of the Sand Hills, Lincoln, Nebraska: Conservation and Survey Division, University of Nebraska, 17-28.
Winter, T.C. 1983: The interaction of lakes with variably saturated porous media. Water Resources Research 19, 1203-18.

Wolfe, S.A., Huntley, D.J., David, P.P., Ollerhead, J., Sauchyn, D.J. and MacDonald, G.M. 2001: Late 18th century drought-induced sand dune activity, Great Sand Hills, Saskatchewan. Canadian Journal of Earth Sciences $38,105-17$.

Yu, Z. and Ito, E. 1999: Possible solar forcing of century-scale drought frequency in the northern Great Plains. Geology 27, 263-66. 